\title{
Biosurfactant production by Pseudomonas aeruginosa isolated from aquaculture farm soil and its optimisation
}

\author{
RANJIT KUMAR NADELLA, MURUGADAS VAIYAPURI, AHAMED BASHA KUSUNUR, \\ TOMS CHERIATH JOSEPH, LALITHA KUTTANAPPILLY VELAYUDHAN AND \\ MUKTESWAR PRASAD MOTHADAKA \\ ICAR-Central Institute of Fisheries Technology, Willingdon Island, Matsyapuri P.O., Kochi - 682 029, Kerala, India \\ e-mail:nranjeetkumar@gmail.com
}

\begin{abstract}
In the present study, aquaculture farm soil was screened for biosurfactant producing bacteria. A total of 43 morphologically distinct colonies were isolated from the farm soil and their biosurfactant production was evaluated employing different screening methods. Fourteen biosurfactant producing bacterial isolates were selected based on the formation of dark blue halos on cetyl trimethyl ammonium bromide (CTAB) agar, emulsification index, oil spreading assay and BATH (Bacterial adhesion to hydrocarbons) assay. Based on the results, the bacterial isolate BHI 9 with highest production of biosurfactant was selected for further studies. The bacterial isolate BHI 9 was found to be Gram negative, slender long rod and oxidase as well as catalase positive. The isolate was identified as Pseudomonas aeruginosa based on 16S rDNA sequence analysis. Optimisation studies were carried out at different temperatures $\left(25,30,35\right.$ and $\left.40^{\circ} \mathrm{C}\right)$ using four different carbon sources $(1 \%)$ i.e., glucose, sucrose, maltose and starch and four nitrogen sources $(1 \%)$ viz., peptone, ammonium nitrate, beef extract and yeast extract, at different $\mathrm{pH}(6,7,8,9$ and 10) and $\mathrm{NaCl}$ levels $(0.5,1.0,1.5$ and 2.0\%). Emulsification index and bacterial biomass $\left(\mathrm{OD}_{600}\right)$ were recorded at 24, 48, 72 and $96 \mathrm{~h}$ intervals. Optimum conditions for biosurfactant production by this bacterium was obtained when glucose and yeast extract were used as carbón and nitrogen sources respectively, maintaining a temperature of $35^{\circ} \mathrm{C}, \mathrm{pH} 8$ and $\mathrm{NaCl} 1.5 \%$, measured in terms of emulsification index and bacterial biomass. This is the first report on biosurfactant producing bacteria isolated from aquaculture farm soil that can find its application in various fields.
\end{abstract}

Keywords: Aquaculture, Biosurfactant, Optimisation, Pseudomonas aeruginosa, Soil

\section{Introduction}

Biosurfactants are diverse group of biological molecules produced by different kinds of bacteria, fungi and yeast (Nitschke et al., 2018). They are heterogeneous type of surface active molecules with distinct physical, chemical and biological properties and have wide range of industrial applications (Satpute et al., 2017; Geetha et al., 2018; Singh et al., 2018). Among different bacteria, Pseudomonads are the best-known bacteria capable of producing biosurfactants by utilising hydrocarbons as carbon and energy sources (Beal and Betts, 2000; Noordman and Janssen, 2002; Saikia et al., 2012). Biosurfactants produced by Pseudomonas sp. from different sources have been studied by various researchers (Ismail et al., 2015; Shekhar et al., 2015; Ji et al., 2016; Geetanjali et al., 2017; Sahebnazar et al., 2018). Similarly, from aquatic sources, Pseudomonas bacterial strains have been isolated and screened for biosurfactant production potential employing different methods. Balan and Jayalakshmi (2013) isolated Pseudomonas aeruginosa from sediment and water samples from Mudasalodai coast and optimised biosurfactant production employing low cost medium. Pepi et al. (2013) isolated P. aeruginosa DG2a strain from aquaculture waste waters and studied biosurfactant production and fatty acid degradation potential. Gomathy and Senthilkumar (2013) isolated and identified potential oil degrading $P$. aeruginosa from harbour waters of Cuddalore, India. Kiran et al. (2014) evaluated glycolipid biosurfactant production by marine bacterium Brachybacterium paraconglomeratum MSA21. Antoniou et al. (2015) studied the capacity of marine bacterial consortium to produce biosurfactant for degrading hydrocarbons. Sadatfaraji et al. (2016) reported on the isolation and identification of biosurfactant producing bacteria from Persian Gulf and evaluated their surfactant activity.

Though much interest is shown towards biosurfactants presently, these do not compete with synthetic surfactants in terms of economics of production. Several studies have been conducted to produce biosurfactants using low cost 
production material and employing engineering processes to increase the yield for reducing production cost (Balan and Jayalakshmi, 2013; Banat et al., 2014; Satpute et al., 2017). Laboratory studies employing microbes need to be conducted for optimisation of biosurfactant production by the microorganisms as it can serve as one of the means for maximum production. Gomathy and Senthilkumar (2013) optimised rhamnolipid type of biosurfactant production by $P$. aeruginosa isolated from marine source. Cost effective technologies for biosurfactant production from renewable substrates was studied by Banat et al. (2014). Sadatfaraji et al. (2016) studied surface tension of biosurfactant producing bacteria at different temperature, salinity, $\mathrm{pH}$ and carbon sources. Sellami et al. (2016) optimised agro processing wastes such as molasses and fish processing byproducts for maximum production of biosurfactant by Aneurinibacillus migulanus. However, there are no reports available on the isolation and identification of biosurfactant producing bacteria from aquaculture farm soil. Therefore, this study attempted to screen aquaculture farm soil for potent biosurfactant producing bacteria as well as to optimise conditions for biosurfactant production.

\section{Materials and methods}

\section{Collection of soil sample}

Soil samples employed in this study were collected from shrimp aquaculture farms located in Ernakulam District, Kerala, India (10. 24' N and 76. 2' E). Top soil (about $1 \mathrm{~cm}$ ) was collected from all the four corners of the farms and pooled to represent the whole farm. Soil samples collected in aseptic sample bags with proper labelling were brought to the laboratory in ice box for further analyses. After reaching the laboratory, the samples were stored in a refrigerator at $4 \pm 0.1^{\circ} \mathrm{C}$ and analysed within $2-4 \mathrm{~h}$ of collection. From each soil sample sub-samples were taken for analysis.

\section{Isolation of biosurfactant producing bacteria}

Bushnell-Hass (BH) medium was used for isolation of biosurfactant producing bacteria (Sahoo et al., 2011). Composition of the medium $\left(\mathrm{g} \mathrm{l}^{-1}\right)$ is as follows: Magnesium sulphate 0.20; Calcium chloride 0.02; Monopotassium phosphate 1.0; Dipotassium phosphate 1.0; Ammonium nitrate 1.0 and Ferric chloride 0.05. All the ingredients were added and the $\mathrm{pH}$ was adjusted to 7.0. For plating, agar $\left(18 \mathrm{~g} \mathrm{l}^{-1}\right)$ was added to the medium.

\section{Enrichment and isolation of pure culture}

Approximately $10 \mathrm{~g}$ of soil was aseptically weighed and added to $\mathrm{BH}$ medium $(90 \mathrm{ml}$ ) supplemented with $2 \%$ diesel and was incubated at $30^{\circ} \mathrm{C}$ for $96 \mathrm{~h}$. The enriched broth $(10 \mathrm{ml})$ was subsequently transferred to fresh broth with diesel oil for isolating pure culture and incubated under same conditions. Biosurfactant producing bacteria, having raised white creamy colour $(2 \mathrm{~mm})$ were isolated by directly plating $0.1 \mathrm{ml}$ of serially diluted enriched samples and spread plated onto the agar plates and incubated at $30^{\circ} \mathrm{C}$ for $96 \mathrm{~h}$. After incubation, well defined isolated colonies were randomly picked and streaked onto $\mathrm{BH}$ medium plate to check for purity. Purified cultures were preserved at $-80^{\circ} \mathrm{C}$ using $60 \%$ glycerol until further use.

Screening of bacterial isolates for biosurfactant production Blue agar plate or CTAB method

For detection of extracellular biosurfactant production, formation of dark halo zone in the plate added with methylene blue and cetyl trimethylammonium bromide (CTAB) was tested as per Siegmund and Wagner (1991). In BH agar medium supplemented with 1.8\% agar, $0.005 \mathrm{~g}$ of methylene blue and $0.2 \mathrm{~g}$ of CTAB was added and sterilised at $121^{\circ} \mathrm{C}$ for $15 \mathrm{~min}$. The culture supernatant $(10 \mu \mathrm{l})$ was added to the plate and kept for incubation for $48 \mathrm{~h}$ at $30^{\circ} \mathrm{C}$. Formation of dark blue halo around the culture was recorded as an indication of ion pairing between anionic biosurfactant and cationic CTAB-methylene blue agar complex (Saravanan and Vijayakumar, 2012).

\section{Emulsification index}

Emulsification activity of the bacterial isolates was measured as per the methods described by Sankar et al. (2013). The culture supernatant $(2 \mathrm{ml})$ was mixed with hydrocarbons such as diesel, petrol and kerosene and vigorous vortexing was done for $3 \mathrm{~min}$. Later, the tubes were left for $24 \mathrm{~h}$ without any disturbance. After $24 \mathrm{~h}$, emulsification activity was estimated as height of emulsified layer/total height x100 (Cooper and Goldenberg, 1987). The experiment was carried out in triplicate and the data presented as mean $\pm \mathrm{SE}$.

\section{Bacterial adhesion to hydrocarbons (BATH) assay}

Hydrophobicity of microbial cell surface was measured by BATH assay as described by Rosenberg et al. (1980) with slight modification. Cells in the exponential growth phase were harvested by centrifugation at $4000 \mathrm{rpm}$ for $10 \mathrm{~min}$ and suspended in phosphate buffered saline to optical density corresponding to 0.5 (AB0). Then diesel was added to the bacterial suspension in the ratio of 3:1 and vortexed for $10 \mathrm{~min}$ at high speed and was left undisturbed for $30 \mathrm{~min}$. Then the optical density of the aqueous phase was measured (AB). The degree of cell hydrophobicity was calculated as: $\mathrm{AB} 0-\mathrm{AB} / \mathrm{AB} 0 \times 100$, where $\mathrm{AB} 0$ is the optical density reading before adding 
diesel and $\mathrm{AB}$ is the optical density reading of aqueous phase (Maneerat and Dikit, 2007). The experiment was carried out in triplicate and the data is given as mean \pm S.E.

\section{Oil spreading method}

The overnight grown bacterial strains were centrifuged for $10 \mathrm{~min}$ at $4000 \mathrm{rpm}$ and the supernatant was collected. Petri plate was filled with $50 \mathrm{ml}$ of distilled water and $20 \mu \mathrm{l}$ of diesel oil was added uniformly on the surface of distilled water. Then $10 \mu$ of culture supernatant was poured on the oil surface and observed for the formation of clear zone, which is an indication of biosurfactant production (Satpute et al., 2008). The experiment was carried out in triplicate and the data is given as mean \pm S.E.

\section{Identification of the bacterial isolate}

Biochemical identification was carried out as per Bergys Manual (Brenner et al., 2004). Molecular identification of the bacterial isolate was carried out by $16 \mathrm{~S}$ r-DNA gene sequencing as per Joseph et al. (2015) using the universal primers $27 \mathrm{~F}$ (5'-AGAGTTTGATCCTGGCTCAG-3') and 1544R (5'-AGAAAGGAGGTGATCCAGCC-3').

\section{Optimisation studies}

Various parameters were optimised using liquid $\mathrm{BH}$ broth for higher production of biosurfactant by the bacterial isolate BHI 9. The observed parameters included (a) temperature, (b) carbon source (diesel oil was replaced with different carbon sources), (c) Nitrogen source, (d) $\mathrm{pH}$ and (e) $\mathrm{NaCl}$ (Table 1). Emulsification index and bacterial density $\left(\mathrm{OD}_{600}\right)$ were measured with the parameter under study as variable one and all other parameters as constant. Series of experiments were conducted in triplicate separately for each parameter and the data is given as mean \pm S.E.

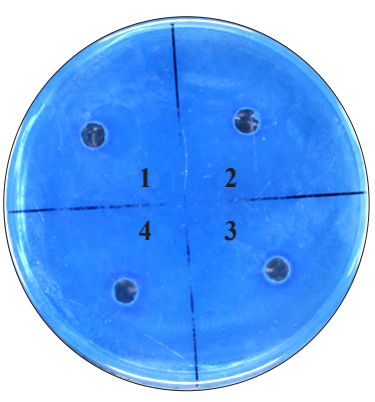

(a)

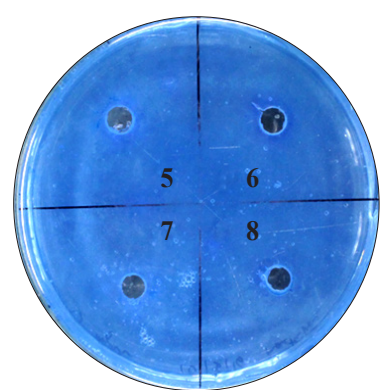

(b)

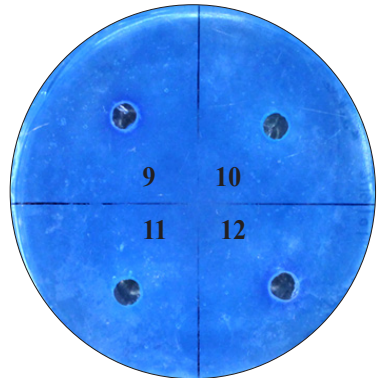

(c)

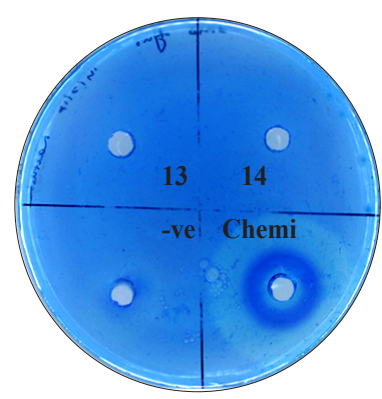

(c)

Fig. 1. Bacterial isolates showing biosurfactant production on $\mathrm{CTAB}$ agar. Formation of dark blue halo indicates the pairing between anionic biosurfactant and cationic CTAB-methylene blue agar complex. a, b, c, d: Biosurfactant producing bacterial isolates (1-14), -ve : Negative control (distilled water), Chemi: Positive control.(TritonX, chemical detergent) 


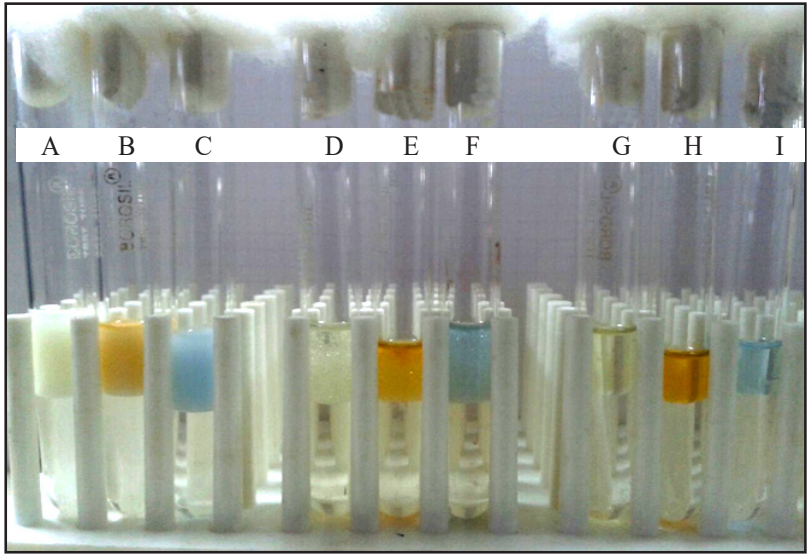

Fig. 2. Emulsification activity of bacterial isolate BHI 9 for biosurfactant production. Test tubes A, D, G - diesel; B, E, H - petrol; C, F, I - kerosene. Triton X (chemical surfactant) is used as positive control (test tubes A, B, C). Bacterial isolate BHI 9 (test tubes D, E, F). Sterile distilled water was used as negative control (test tubes $\mathrm{G}, \mathrm{H}, \mathrm{I})$

\section{Identification of the bacterial isolate}

Biochemical identification of the bacterial isolate BHI 9 revealed that the bacterium is Gram negative, long and slender rod, oxidase positive and catalase positive. Molecular characterisation showed that the bacterial isolates belonged to $P$. aeruginosa (Fig. 3). The sequences were submitted in NCBI GenBank with the accession no. MH050428.

\section{Optimisation studies}

The biosurfactant production by BHI 9 was optimised under different conditions. Emulsification index and bacterial biomass was found maximum at $35^{\circ} \mathrm{C}$, glucose as carbon source, yeast extract as nitrogen source, $\mathrm{pH} 8$ and $\mathrm{NaCl} 1.5 \%$ (Fig. 4 and 5). Growth of the bacterial cells and the biosurfactant production depends on composition of the medium, agitation, temperature and pH (Desai and Banat, 1997; Sahoo et al., 2011). In addition, salt concentrations in the medium also show

Table 2. Screening of bacterial isolates for biosurfactant production by emulsification index, oil spreading assay and BATH assay

\begin{tabular}{llllll}
\hline \multirow{2}{*}{ Isolate } & \multicolumn{3}{c}{ Emulsification index (\%) } & & Oil spreading assay (cm) \\
\cline { 2 - 4 } & Diesel & Petrol & Kerosene & & 3.13 \\
\hline B2F15 & 2.5 & 8.5 & 2.8 & 0.3 & 8.54 \\
B2F14 & 2.5 & 2.8 & 2.8 & 1 & 20.2 \\
B9F12 & 7.5 & 14.2 & 5.71 & 3 & 5.3 \\
B2F9 & 2.5 & 2.8 & 2.8 & 1.8 & 3.9 \\
B2H7 & 2.5 & 2.8 & 2.8 & 0.8 & 10.3 \\
B2F16 & 2.5 & 5.71 & 5.71 & 1 & 5.51 \\
BHA12 & 5 & 5.71 & 5.71 & 0.8 & 7.43 \\
B2H6 & 5 & 5.71 & 5.71 & 2 & 4.39 \\
BHA11 & 2.8 & 2.8 & 2.8 & 1.3 & 2.3 \\
BHA10 & 2.5 & 5.71 & 2.8 & 1.5 & 1.2 \\
B2H8 & 2.5 & 2.8 & 2.8 & 1 & 25.3 \\
BHA9 & 25 & 31.4 & 40 & 3.5 & 14.9 \\
BHA6 & 12.5 & 15 & 10 & 3 & 6.4 \\
BHA8 & 7.5 & 10 & 5 & 2 & \\
\hline
\end{tabular}

Values are represented as average of triplicate readings

by microorganisms as an excretory product which is responsible for emulsification of hydrocarbon. Oil spreading assay is a rapid and easy method which is used for screening of biosurfactant producing bacteria (Youssef et al., 2004). It measures the diameter of the zone formed on the oil surface when biosurfactant is present in the sample. The isolate BHI 9 formed a zone of $3.5 \mathrm{~cm}$ on the oil surface. BATH assay is also a simple and indirect method for screening cell hydrophobicity of the biosurfactant producing bacteria. If the bacteria is having the property of adhering to hydrocarbon, that will be useful for determination of degree of bacterial adherence. In this study BHI 9 showed $25.3 \%$ bacterial adherence. effect on biosurfactant production by altering cellular activity ((Ilori et al., 2005; Gapke et al., 2007). Water soluble compounds such as glucose and sucrose have been reported as a carbon source for biosurfactant production (Rahman et al., 2002). Tuleva et al. (2002) reported that Pseudomonas putida 21BN strain produced highest emulsifying activity when soluble substrates (glucose) or poorly soluble substrates (hexadecane) were used as carbon source. Similarly, Sahoo et al. (2011) observed that $P$. aeruginosa $\mathrm{OCD} 1$ produced maximum biosurfactant at $1 \%$ inoculum, $2 \%$ n-octane as carbon source, optimum temperature between 30 and $35^{\circ} \mathrm{C}$, shaking speed $125 \mathrm{rpm}$ and $\mathrm{pH}$ 6. Gomathy and Senthilkumar (2013) optimised 


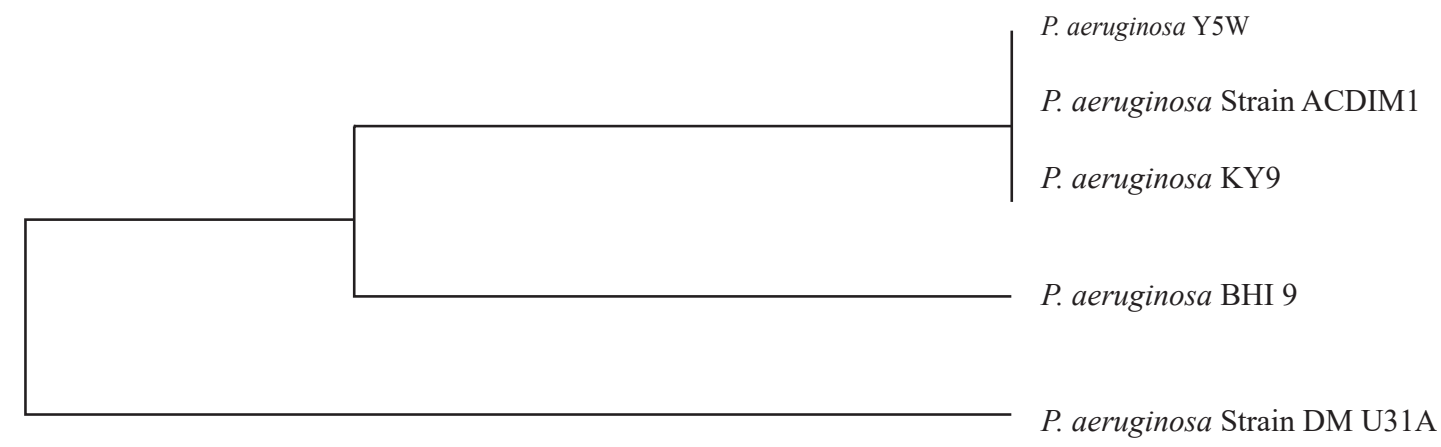

Fig. 3. Phylogenetic tree of the biosurfactant producing bacterial strain Pseudomonas aeruginosa BHI 9 based on the 16S rDNA gene sequences (neighbor joining tree method). The reference strains were collected from the gene sequences available in NCBI (BLASTn) domain

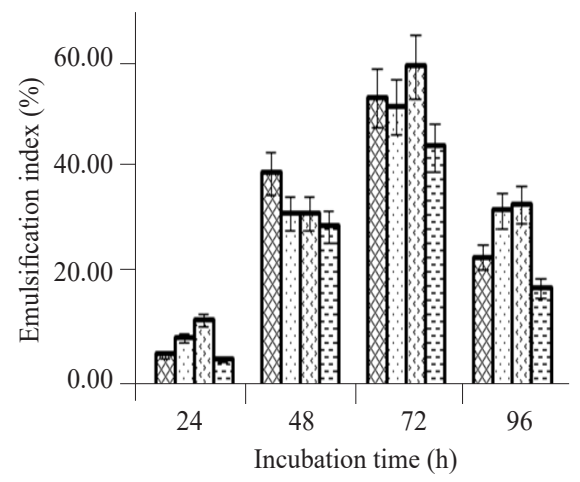

๒ $25^{\circ} \mathrm{C}, \square 30^{\circ} \mathrm{C}$, $35^{\circ} \mathrm{C}$, 田 $40^{\circ} \mathrm{C}$

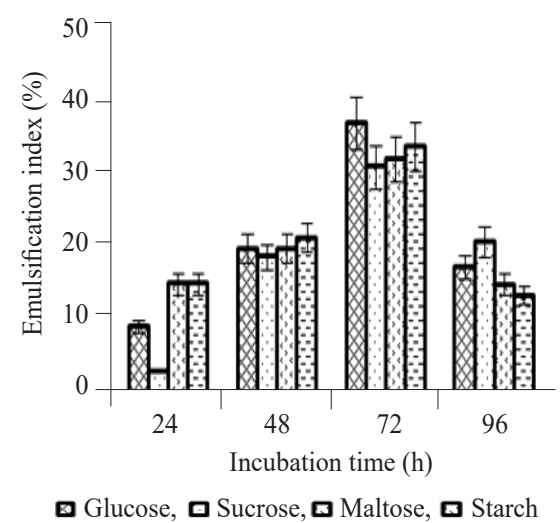

(b)

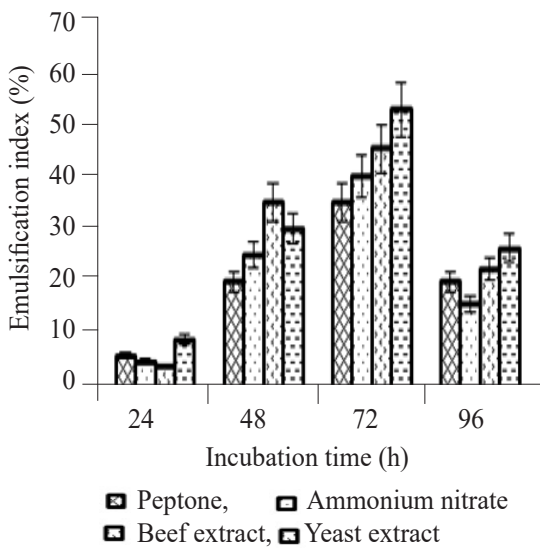

(c)

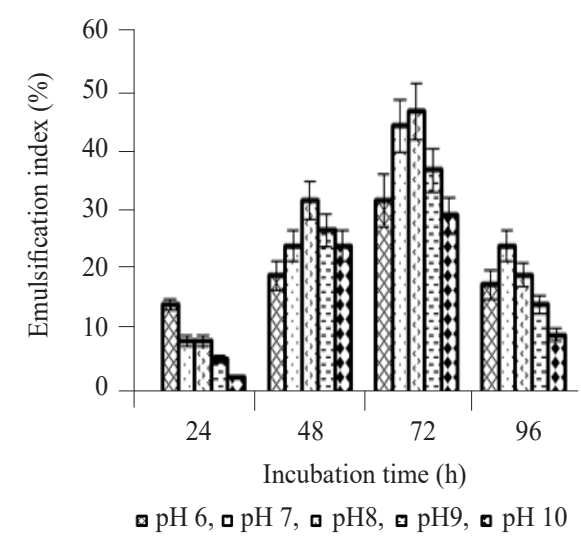

(d)

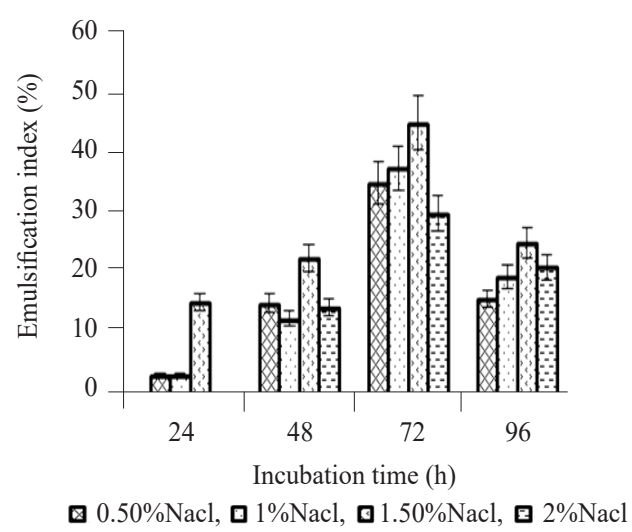

(e)

Fig. 4. Emulsification index* for biosurfactant production by Pseudomonas aeruginosa BHI 9 at different (a) temperatures; (b) carbon source; (c) nitrogen source; (d) $\mathrm{pH}$ and (e) $\mathrm{NaCl}$. Incubation was carried out at $30^{\circ} \mathrm{C}$ at $125 \mathrm{rpm}$ for 24, 48, 72 and $96 \mathrm{~h}$. ${ }^{*}$ Mean \pm S.E, $n=3$

rhamnolipid production by $P$. aeruginosa at $35^{\circ} \mathrm{C}, \mathrm{pH}$, $\mathrm{NaCl} 1.5 \%$, ammonium nitrate as nitrogen source and sucrose as carbon source. Sadatfaraji et al. (2016) showed biosurfactant production by $P$. aeruginosa was best at $37^{\circ} \mathrm{C}$ and $\mathrm{pH}$ of $6.5-7.5$.
In the present study, indigenous biosurfactant producing bacteria isolated and identified from aquaculture farm soil, particularly $P$. aeruginosa (BHI 9) showed good biosurfactant activity. The optimum conditions for maximum biosurfactant production by the 


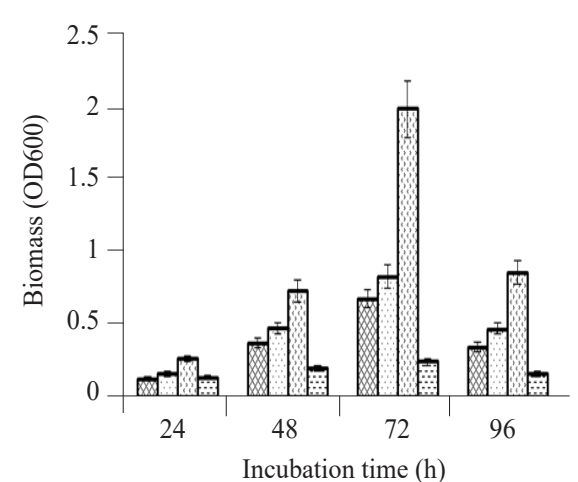

$25^{\circ} \mathrm{C}$, $30^{\circ} \mathrm{C}$, $35^{\circ} \mathrm{C}$, $40^{\circ} \mathrm{C}$

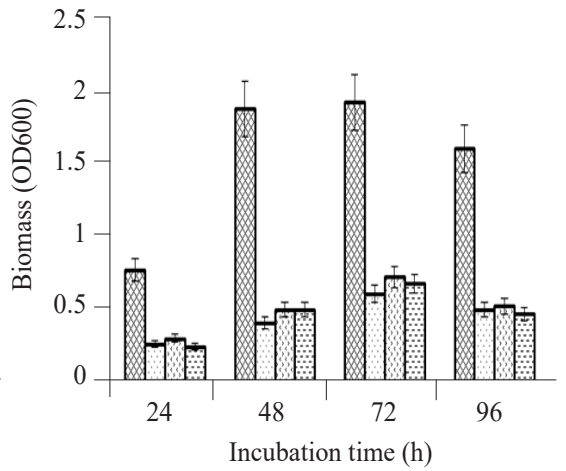

․ Glucose, $\boldsymbol{\square}$ Sucrose, $\boldsymbol{\square}$ Maltose, $\boldsymbol{\Xi}$ Starch

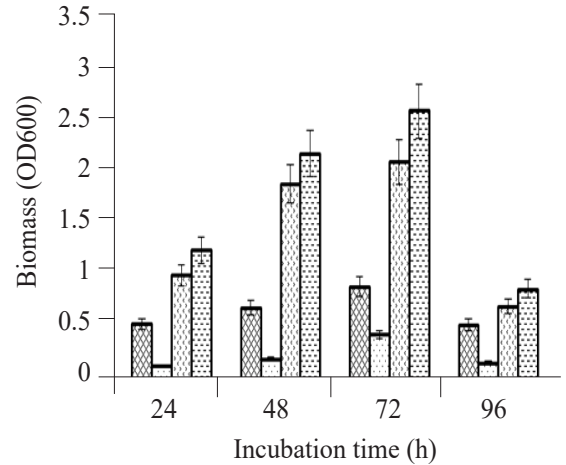

口 Peptone, ․ Ammonium nitrate — Beef extract, $\square$ Yeast extract

(c)

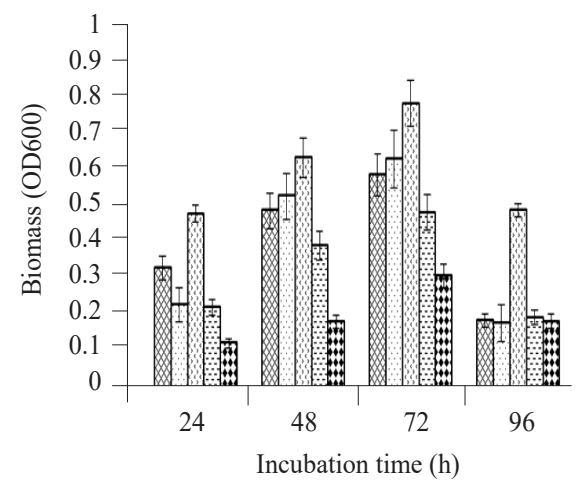

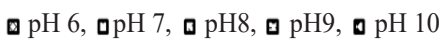

(d) (b)

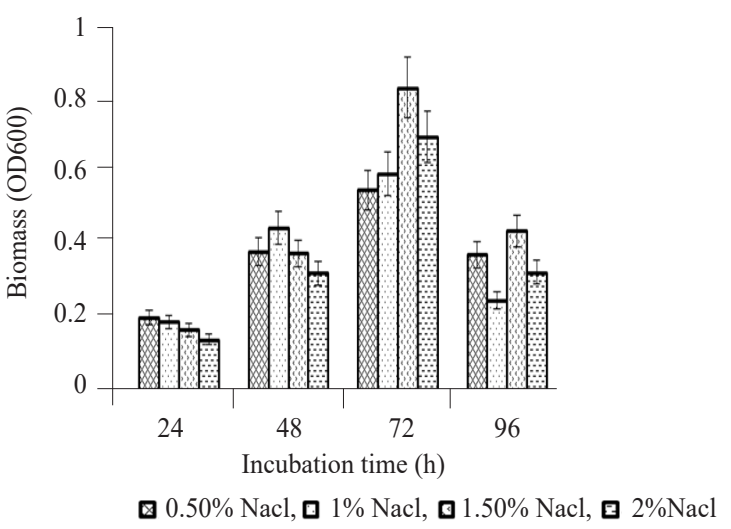

(e)

Fig. 5. Bacterial biomass * $\left(\mathrm{OD}_{600}\right)$ recorded by Pseudomonas aeruginosa $\mathrm{BHI} 9$ at different (a) temperatures; (b) carbon source; (c) nitrogen source; (d) $\mathrm{pH}$ and (e) $\mathrm{NaCl}$. Incubation was carried out at $30^{\circ} \mathrm{C}$ at $125 \mathrm{rpm}$ for $24,48,48$ and $96 \mathrm{~h}$. ${ }^{*} \mathrm{Mean} \pm \mathrm{S} . \mathrm{E}$, $\mathrm{n}=3$

bacterial isolate $\mathrm{BHI} 9$ was obtained at temperature $35^{\circ} \mathrm{C}$, $\mathrm{pH} 8, \mathrm{NaCl} 1.5 \%$, glucose as carbon source and yeast extract as nitrogen source. The biosurfactant produced by $P$. aeruginosa would find applications in bioremediation, food industry, pharmaceutical sector and cosmetics industry. In aquaculture, it could be used as binding agent during feed preparation and as antimicrobial agent.

\section{Acknowledgements}

Authors are grateful to the Director, ICAR-CIFT, Kochi, India, for providing all the facilities required for the present study and to ICAR, New Delhi, India, for the financial support.

\section{References}

Antoniou, E., Fodelianakis, S., Korkakaki, E. and Kalogerakis, N. 2015. Biosurfactant production from marine hydrocarbondegrading consortia and pure bacterial strains using crude oil as carbon source. Front. Microbiol., 6: 274. doi.org/10.3389/fmicb.2015.00274.
Balan, S. S. and Jayalakshmi, S. 2013. Glycolipid biosurfactant production using low cost medium from marine bacterium Pseudomonas aeruginosa of Mudasalodai coast. Int. J. Green Chem. Bioprocess, 3(3): 33-37.

Banat, I. M., Satpute, K. S., Cameotra, S. S., Patil, R. and Narendra, V. N. 2014. Cost effective technologies and renewable substrates for biosurfactants' production. Front. Microbiol., 5: 697. doi.org/10.3389/fmicb.2014.00697.

Beal, R. and Betts, W. B. 2000. Role of rhamnolipid biosurfactants in the uptake and mineralisation of hexdecane in Pseudomonas aeruginosa. J. Appl. Microbiol., 89: 158-168. doi.org/10.1046/j.1365-2672.20 00.01104.x.

Brenner, D. J., Krieg, N. R. and Staley, J. T. 2004. The proteobacteria, Part B: The Gammaproteobacteria. In: Garrity, G., Brenner, D. J., Krieg, N. R. and Staley, J. R. (Eds.), Bergey's manual of systemic bacteriology, vol. 2. $1106 \mathrm{pp}$. 
Cooper, D. G. and Goldenberg, B. G. 1987. Surface-active agents from two Bacillus species. Appl. Environ. Microbiol., 53: 224-229.

Desai, J. D. and Banat, I. M. 1997. Microbial production of surfactants and their commercial potential. Microbiol. Mol. Biol. Rev., 61(1): 47-64.

Gakpe, E., Pattanathu, K. S., Rahman, M. and Hatha, A. A. M. 2007. Microbial biosurfactants - Review. J. Mar. Atmos. Res., 3(2): 1-17.

Geetanjali, R. K., Prajnya, A. M., Shruti, A. J., Sunita, N., Bhushan, B. K. Potadar, R. R., Kalebar V. U., Shinde, H., Parimala, C. P., Shetti, A. A. and Hiremath, S. V. 2017. Isolation and characterisation of biosurfactant produced by soil isolates Pseudomonas species and Rhodococcus sp. J. Pharmacy Biol. Sci., 12(5): 17-20. DOI: 10.9790/30081205011720 .

Geetha, S. J., Banat, I. M. and Joshi, S. J. 2018. Biosurfactants: Production and potential applications in microbial enhanced oil recovery (MEOR). Biocatal. Agri. Biotechnol., 14: 3-32. doi.org/10.1016/j.bcab.2018.01.010.

Gomathy, C. and Senthilkumar, R. 2013. Production of rhamnolipid biosurfactant from a marine Pseudomonas aeruginosa. Int. J. Res. Environ. Sci. Tech., 3(3): 86-91.

Ilori, M. O., Amobi, C. J. and Odocha, A. C. 2005. Factors affecting the production of oil degrading Aeromonas sp. isolated from a typical environment. Chemosphere, 61: 985-992. doi.org/10.1016/j.chemosphere.2005.03.066.

Ismail, W., Shammary, S. A., El-Sayed, W. S., Obuekwe, C., El Nayal, A. M., Raheem, A. S. A. and Al-Humam, A. 2015. Stimulation of rhamnolipid biosurfactants production in Pseudomonas aeruginosa AK6U by organosulfur compounds provided as sulfur sources. Biotechnol. Rep., 7: 55-63. doi.org/10.1016/j.btre.2015.03.001

Ji, F., Li, L., Ma, S., Wang, J. and Bao, Y. 2016. Production of rhamnolipids with a high specificity by Pseudomonas aeruginosa M408 isolated from petroleum-contaminated soil using olive oil as sole carbon source. Ann. Microbiol., 66(3): 1145-1156. doi.org/10.1007/s13213-016-1203-9.

Joseph, T. C., Murugadas, V., Reghunathan, D., Shaheer, P., Akhilnath, P. G. and Lalitha, K. V. 2015. Isolation and characterisation of Vibrio cholerae 0139 associated with mass mortality in Penaeus monodon and experimental challenge in post-larvae of three species of shrimps. Aquaculture, 442: 44-47. doi.org/10.1016/j. aquaculture.2015.02.020.

Kiran, G. S., Sabarathnam, B., Thajuddin, N. and Selvin, J. 2014. Production of glycolipid biosurfactant from spongeassociated marine actinobacterium Brachybacterium paraconglomeratum MSA21. J. Surfactant. Deterg., 17(3): 531-542. doi.org/10.1007/s11743-014-1564-7.

Lin, S. C., Lin, K. G., Lo, C. C. and Lin, Y. M. 1998. Enhanced biosurfactant production by Bacillus licheniformis mutant.
Enzyme Microb. Technol., 23: 267-273. doi.org/10.1016/ S0141-0229(98)00049-0.

Maneerat, S. and Dikit, P. 2007. Characterisation of cellassociated bioemulsifier from Myroides sp. SM1, a marine bacterium. Songklanakarin J. Sci. Technol., 29(3): 769-779.

Nitschke, M. and Silva, S. S. E. 2018. Recent food applications of microbial surfactants. Crit. Rev. Food Sci. Nutr., 58(4): 631-638. doi.org/10.1080/10408398.2016.1208635.

Noordman, W. H. and Janssen, D. B. 2002. Rhamnolipid stimulates uptake of hydrophobic compounds by Pseudomonas aeruginosa. Appl. Environ. Microbiol., 68: 4502-4508. doi: [10.1128/AEM.68.9.4502-4508.2002].

Pepi, M., Focardi, S., Lobianco, A., Angelini, D. L., Borghini, F. and Focardi, S. E. 2013. Degradation of fatty acids and production of biosurfactant as an added value, by a bacterial strain Pseudomonas aeruginosa DG2a isolated from aquaculture wastewaters. Water Air Soil Pollut., 224: 1772. doi.org/10.1007/s11270-013-1772-1.

Rahman, K. S. M., Banat, I. M., Rahman, T. J., Thayumanavan, T. and Lakshmanaperumalsamy, P. 2002. Bioremediation of gasoline contaminated soil by bacterial consortium amended with poultry litter, coir pith and rhamnolipid biosurfactant. Biores. Tech., 81: 25-32. doi.org/10.1016/ S0960-8524(01)00105-5.

Rosenberg, M., Gutnick, D. L. and Rosenberg, E. 1980 Adherence of bacteria to hydrocarbons: a simple method for measuring cell-surface hydrophobicity. FEMS Microbiol. Lett., 9: 29-33.

Sadatfaraji, F. B., Bhatti, A. B., Behzadi, F., Khani, M. and MortezaKhani, M. 2016. Microbial production of biosurfactants from the marine environment. Micro. Nano Biomed., 1(1): 28-34.

Sahebnazar, Z., Mowla, D. and Karimi, G. 2018. Enhancement of Pseudomonas aeruginosa growth and rhamnolipid production using iron-silica nanoparticles in low-cost medium. J. Nanostructures, 8(1): 1-10. DOI: 10.22052/ JNS.2018.01.001

Sahoo, S., Datta, S. and Biswas, D. 2011. Optimisation of culture conditions for biosurfactant production from Pseudomonas aeruginosa OCD1. J. Adv. Sci. Res., 2(3): 32-36.

Saikia, R. R., Deka, S., Deka, M. and Banat, I. M. 2012. Isolation of biosurfactant producing Pseudomonas aeruginosa RS29 from oil-contaminated soil and evaluation of different nitrogen sources in biosurfactant production. Ann. Microbiol., 62: 753-763. doi.org/10.1007/s13213-011-0315-5.

Sankar, S., Balan, S. S. and Jayalakshmi, S. 2013. Effect of biosurfactant as antibiotic role against fungal pathogens in fish Chirrinus mirgala. Int. J. Cur. Tr. Res., 2(1): 338-344.

Saravanan V. and Vijayakumar. S. 2012. Isolation and screening of biosurfactant producing microorganisms from oil contaminated soil. J. Acad. Indus. Res., 1(5): 264-268. 
Satpute, S. K., Płaza, G. A. and Banpurkar, A. G. 2017. Biosurfactants' production from renewable natural resources: Example of innovative and smart technology in circular bioeconomy. Manag. Sys. Prod. Eng., 25(1): 46-54. doi.org/10.1515/mspe-2017-0007.

Satpute, S. K., Bhawsar, B. D., Dhakephalkar, P. K. and Chopade B. A. 2008. Assessment of different screening methods for selecting biosurfactant producing marine bacteria. Ind. J. Mar. Sci., 37: 243-250.

Sellami, M., Khlifi, A., Frikha, F., Miled, N., Belbahri, L. and Rebah, F. B. 2016. Agro-industrial waste based growth media optimisation for biosurfactant production by Aneurinibacillus migulanus. J. Microbiol. Biotech. Food Sci., 5(6): 578-583. doi: 10.15414/jmbfs.2016.5.6.578-583.

Shekhar, S., Sundaramanickam, A. and Balasubramanian, T. 2015. Biosurfactant producing microbes and their potential applications: A review. Crit. Rev. Environ. Sci. Technol., 45(14): 1522-1554. doi.org/10.1080/10643389.2014.955631.
Siegmund, I. and Wagner, F. 1991. New method for detecting rhamnolipids excreted by Pseudomonas species during growth on mineral agar. Biotechnol. Tech., 5: 265-268. doi.org/10.1007/BF02438660.

Singh, P., Patil, Y. and Rale, V. 2018. Biosurfactant production: emerging trends and promising strategies. J. Appl. Microbiol., doi.org/10.1111/jam.14057.

Thavasi, R., Sharma, S. and Jayalakshmi, S. 2011. Evaluation of screening methods for the isolation of biosurfactant producing marine bacteria. J. Pet. Environ. Biotechnol., S1: 001. doi:10.4172/2157-7463.S1-001.

Tuleva, B. K., Ivanov, G. R. and Christova, N. E. 2002. Biosurfactant production by a new Pseudomonas putida strain. Z. Naturforsch. C., 57(3-4): 356-60. DOI: 10.1515/ znc-2002-3-426.

Youssef, N., Duncan, K. and Nagle, D. 2004. Comparison of methods to detect biosurfactant production by diverse microorganisms. J. Microbiol. Methods, 56(3): 339-347. doi.org/10.1016/j.mimet.2003.11.001. 